\title{
Development of Human Resources in the Globalization Era
}

\author{
Ricky Herlambang Ahmad Ja'far \\ Department of Educational Administration \\ Universitas Negeri Malang, Indonesia \\ rickyherlambang80@yahoo.com
}

Firman Budi Santoso

Department of Educational Administration

Universitas Negeri Malang, Indonesia

firmanbudisantoso100@gmail.com

\author{
Risa Oktavianingrum \\ Department of Educational Administration \\ Universitas Negeri Malang, Indonesia \\ risaoktavianingrum23@gmail.com
}

\author{
Nila Octavia Yulindasari \\ Department of Educational Administration \\ Universitas Negeri Malang, Indonesia \\ 1999nilaoctavia@gmail.com
}

\begin{abstract}
The purpose of this study was to determine the development of human resources in encounter globalization era in the Sub-Department of Civil Service Graha Rector of the State University of Malang. This study uses a qualitative observation method with data sources, namely the head of staffing at the State University of Malang. Data collection techniques are carried out by observation, interviews and documentation. Data analysis techniques in this study are collecting data, data reduction, data presentation, and data verification. The results showed that the development of human resources carried out by the staff of the State University of Malang was: (1) training, (2) training, (3) employee self-actualization, and (4) improvement of the recruitment system.
\end{abstract}

Keywords: human resource development, globalization, employee competency

\section{INTRODUCTION}

Human resources are an important element of the passage of an organization in realizing the objectives. SDM is the perpetrator in the activities of planning, management and implementation (substance management). Human resource management provides an approach in managing human problems. Not only that, human resource management is the way or the utilization of every human resource to develop according to skill. Its implementation, human resource management provides benefits in each individual doing its actualization.

In the current era of globalization, it is necessary to develop human resource to deal with digitization and tight global competition, in the field of education, human resources have many problems. This problem has many causes, ranging from the low quality of education, soft skill even self-developing consciousness less. According to Sri Mulyani said that human resources in Indonesia are not accompanied by skilled skills (Yovanda, 2017). This less capable expertise can come from a lack of awareness of self-esteem or can also come from the quality of education. Not only that, the problem of income or the right of employees is also problematic. For example, the income of honorary teachers in Indonesia is less feasible. Indecent income by Indonesian honorary teachers will affect the quality of the teacher's performance. Such influence is like lack of skill or low teaching spirit from the honorary teacher.

In dealing with these problems, an organization can conduct a human resources development program. The Human resources development Program provides each individual to thrive in order to achieve a goal agreement. In its essence, development is learning to meet long-term needs. The development can be formal and non-formal development through stages (Ulfatin and Triwiyanto, 2016).

Utami (2017) explains there are several strategies that can be done to deal with the era of globalization for human resources, among others through training, education, coaching, recruitment, system change, opportunity, and appreciation. Through this strategy that is done systematically and continuously will produce excellent quality of human resources and able to compete in the era of globalization.

\section{METHOD}

This type of research uses qualitative observation methods. Qualitative research suggests the state of the object or subject is examined in accordance with the use of observation mechanisms, interviews and documentation through the speaker's voice recordings. Qualitative research is also referred to as naturalistic, meaning that qualitative research is what it is. So, according to what the utility found in the field.

The research was conducted in Chairman of Human Resource at Malang State University. The case study is a direct method of observation by focusing on a single point of research object. Case studies are in line with this research with a focus on one event i.e. human resource development. Interviews conducted around questions with the aim to know how to process human resources development to face the era of globalization, activities such as what is done, advantages and weaknesses of the development process, and evaluation for employees who have not fulfilled the classification even if they follow the development process.

\section{RESULT}

The process of human resources development in the Chairman of Human Resource of State University of Malang is through training, trainings, self-actualization of employees and system improvement in the recruitment process. The most common problem is when there is no budget to hold an activity to develop human resources, so employees spend their own expenses and can use employee self-actualization as an effort in the process Human resources development.

In this era of globalization today the problem faced is how a clerk who lacks in operating a computer or a lack of understanding the science of technology. For the 
problem, the speaker said that the center of ICT State University of Malang annually held a computer training. The activity aims to increase the knowledge of education personnel in the field of technological sciences and can follow the flow of the development era. Referring to the answers the training is limited to about 5 people each faculty.

Training activities are conducted to ensure employees to develop careers and academic office of officers. Where the speaker explained that starting from 2019 there are new regulations regarding civil servants and non-civil servants will be held a work agreement. Training carried out for 4 days where employees will be given formal insights, for other insights employees are expected to seek information as a form of development of him. Speaker also explained in the era of globalization is currently the shortage of employees is less timely. Through this training process is expected to overcome the problem with the discipline in training activities conducted.

According to an interview speaker there is never a denying the offer of training activities or trainings on the development of human resources, but the absence of budget for the activities then the personnel said that selfactualization is the most Effective education to be able to develop its potential. Employee self-actualization is adjusted to its position, such as lecturers can actualize themselves by writing books, journals and others.

The recruitment process can also affect the development of human resources in the globalization era, with the demands of globalization, which demonstrates how the rapid flow of information is required by competent personnel and is thoroughly prepared to Challenges of globalization era. The informant describes the recruitment process should have the addition of Soft skill selection so that the selectors understand the right to be given the opportunity to work, not only look at the qualifications and results of interviews. Providing gifts, mutations and promotions to achievers can also motivate employees to continue to develop their potential.

\section{DISCUSSION}

In this era of globalization, employees are required to always follow the flow, therefore it is necessary to develop both conceptually and technically. According to research results human resources development through training and trainings will always be done both formal training and informal training. Trainings and formal training mean that employees are assigned by an institution to participate in training, while training or informally trained officers have the initiative to develop themselves. Budget limitation issues can be addressed with non-formal training. This is in agreement with Hasibuan (2007) which states there are two types of human resources development, namely formal development and informal development. Formal development is the development of officers assigned by the institution to participate in training or trainings in the institution itself or training Institute. This development aims to fulfill the competency for existence and sustainability of the institution. Informal development means development on the basis of the wishes and needs of employees individually.
Self-actualization can also be said as a form of human resources development because it is the use of all talents, interests, potentials, and the use of all quality and capacity in full or also can be said that self-actualization is Development of the highest human resources. Because of the highest self-actualization of development then the lowest priority to be developed. This is in accordance with the theory of Goldstein which mentions that selfactualization is required is a whole self-realization organism Suppose when someone wants to be smart then he will learn. Self-actualization is a human creativity to develop themselves (Suryabrata, 2006).

In facing the era of globalization, the improvement of the recruitment system is also very important role because the increasingly tight competition and the current rapid technological development required officers who are really ready to face the challenge. Employees are not only highly qualified but must also have the commitment, ability, and competence required by the institution. This agreed with the opinion of Noe et.al (2008) explaining that recruitment is the initial activity of an institution to find a workforce that is ready to respond to challenges as well as potential. There are several aspects that the institution has to do in making recruitment decisions that are personnel policies, recruitment sources, and the character and behavior of job applicants.

\section{CONCLUSION}

Globalization cannot be avoided at this time, with the rapid development of technology, the development of human resources must be admitted to face the challenge. Officers must have the initiative to expand themselves in order to be able to overcome the problem and avoid mutation and be dismissed by the institution. The Institute also provides training programmed or trainings so that organizations will not lose their competition in the globalization era, but the return on the budget constraints on training or personnel needs to be initiative and be responsive to Existing developments.

Self-actualization is also regarded as an employee's self-development to gauge how far the competency, talent and potential of the employee is. Selfactualization is the culmination of every individual's need, so when the need is enough for the employee to be self-actualization. Recruitment in times of globalization should emphasize the quality of employees' competence, not the close proximity of leaders who have always been a problem recruitment today. Competency based recruitment will help institutions to remain in existence and will not be immersed in the competition of globalization because the employees are ready to face the challenges of globalization.

\section{REFERENCE}

[1] Hasibuan, M. S. P. 2007. Manajemen Sumber Daya Manusia. Jakarta: Bumi Aksara.

[2] Noe, R. A. 2008. Fundamentals of Human Resource Management. New York: Mc.Graw Hill

[3] Rahmat, P.S. 2009. Penelitian Kualitatif. Jurnal Equilibrium, 5, 1-8.

[4] Suryabrata, S. 2006. Psikologi Pendidikan. Jakarta: PT Raja Grafindo Persada. 
[5] Ulfatin, N., \& Triwiyanto, T. 2016. Manajemen Sumber Daya Manusia Bidang Pendidikan. Jakarta: PT Raja Grafindo Persada

[6] Yovanda. 2017. Sri Mulyani Soroti Kualitas Sumber Daya Manusia. Retrieved 23 July 2019, from https://ekbis.sindonews.com/read/1193791/33/sri-mulyanisoroti-kualitas-sumber-daya-manusia-indonesia1491201140. 